sensitive cells. He pointed out that the problems to which it is intended to apply them are often mainly optical, electrical or mechanical. Audible warnings are sometimes given of the opening or closing of lift gates and announcing the record of automatic weighing machines. They will also be used on automatic telephone exchanges for announcing the correct time. Great demands on photo-cells will soon be made in television transmission. They are used for transmitting pictures by wire and radio. Other uses described were in counting objects, like cigarettes, passing along a conveyor, in giving warning when the web fractures on high-speed printing machines, for burglar alarms, smoke detection in factory chimneys, regulating the speed of escalators and the timing of sporting events. L. H. MeDermott described three different ways in which photo-cells have been used in connexion with problems of daylight illumination. The first was a relay to control the lighting of part of the National Portrait Gallery, the second was a device for the continuous recording of the amount of daylight illumination at Teddington and the third was used in the investigation now being carried out at the National Physical Laboratory into the lowest value of natural illumination which an office worker requires. In the third paper, W. H. B. Hall described an interesting device by which the automatic lighting and extinguishing of gas lamps at a London school was controlled by means of a photo-cell.

\section{Technical Exhibition at Glasgow}

A TECHNICAL exhibition was held in the Royal Technical College, Glasgow, on April 24-25. This exhibition was organised by the students of the College for two purposes : to provide the public with an opportunity of inspecting the College, and to provide past and present students and their friends with the opportunity of meeting one another socially. During these days each Department of the College was open for inspection, and was demonstrating the processes illustrating the various subjects studied in the College. In addition, the students obtained the co-operation of nearly forty outside firms, which sent numerous exhibits to supplement those on view in the Departments. The exhibition was officially opened by Mr. J. W. Peck, secretary of the Scottish Education Department; Mr. G. M. Smith being in the chair. The public was given the opportunity, for the first time, of viewing the wind tunnel recently installed in the Department of Mechanical Engineering for the purpose of aeronautical research, and also the distillation plant which was presented six months ago to the Technical Chemistry Department. Other exhibits of interest included a demonstration of television, glass-blowing, metal-spraying, spectrographic analysis, ultra-violet radiation, and many others that were of interest not only to the scientifically trained person, but also to the public. A Former Students' Association has been formed, and the inaugural meeting was held immediately after the opening ceremony, Mr. J. W. Peck being the chairman.

\section{Fire and Vegetation}

THrs very debatable subject has recently been discussed from a very statesmanlike point of view by a South African botanist, Prof. John F. V. Phillips (J. South African Bot., 2, Part 1). It is pointed out that whilst such characteristic native vegetation as the beautiful 'fijnbos' (the macchia or maquis of the south-west Cape) may be irretrievably damaged by fire, and whilst there is every reason for excluding fire definitely from the water conservation areas, yet on the other hand there is also clear evidence that controlled firing, carried out at the proper season, may encourage the subsequent establishment of better pasture grasses. Further, it may be argued that absence of fires, coupled with overstocking, has contributed to a marked increase in the prevalence of the woody overgrowth, especially of species of Acacia, which has led to a deterioration in the pastoral value of much tree-and-grass savanna. There is thus evidence of a need for protection of certain land from any type of fire treatment, whilst in other localities an early application of controlled fire treat. ment is probably desirable. Such a problem requires action by a responsible body, and Prof. Phillips suggests that the Minister of Agriculture and Forestry should act as chairman of a special Commission of Conservation which should formulate a policy and co-ordinate the functions of the various Government departments involved in the carrying out of this policy. Important legal and administrative problems are concerned. The matter is regarded as urgent by Prof. Phillips, who concludes that uncontrolled firing is costing South Africa untold millions and "creating for posterity a most serious state of affairs, which no amount of money ever would be capable of putting right".

\section{Seed Oats for Hill Districts}

Authough oats are still an important crop in Wales, a variety suitable to the particular conditions of the hill districts has been a long-felt want. Up to the present, Avena strigosa or Ceirch Llwyd has been grown on this type of land, and although it is essen. tially a variety for wet districts and poor land, it has the great disadvantage of not yielding a good sample, being heavily awned and consequently difficult to thresh. Breeding experiments with Avena strigosa carried out at the Welsh Plant Breeding Station have, however, resulted in the production of a new variety, Ceirch Llwyd Cwta S. 171, which is described in Leaflet Series S. No. 3, issued by the University College of Wales, Aberystwyth (price 1s.). The chief point of interest lies in the fact that it is awnless, but in addition it yields well or better than the older variety, the grain is heavier, the bushel weight higher and the protein content greater ; finally, it shows a resistance to both loose and covered smut. The amount of seed available for sowing this spring (1936) is about five tons, the wholesale price being 20s. per cwt. Co-operative societies, merchants and farmers interested in the new variety are asked to communicate with the Station at the earliest opportunity, as unless accurate estimation of the demand is obtained, 